\title{
Otoimmün Tirotoksik Nöropati - Olgu Sunumu
}

\author{
Autoimmune Thyrotoxic Neuropathy - A Case Report
}

\author{
Murat ALPUA ${ }^{1}$, Fikri AK ${ }^{2}$ \\ ${ }^{I}$ Çankırı Devlet Hastanesi, ÇANKIRI \\ ${ }^{2}$ S.B. Ankara Numune Hastanesi Nöroloji Kliniği, ANKARA
}

\begin{abstract}
ÖZET
Nörolojik patolojilerin etyolojisinde tiroid disfoksiyonlarının da olduğu her zaman akla getirilmesi gereken bir gerçektir. Hipertiroidi ve hipotiroidinin tremor, kognitif bozukluk, ajitasyon, tuzak nörotikler, duygudurum bozuklukları, epileptik nöbetler, başağrısı, nöropatiler, ensefalopati gibi birçok nörolojik patoloji ile ilişkili olduğu tespit edilmiştir.

36 yaşında kadın hasta 1.5 aydır başlayan ellerinde kuvvetsizlik ve yürüyememe şikayeti ile başvurdu. Özgeçmiş, soygeçmiş ve nörolojik anamnezinde bir özellik yoktu. Nörolojik muayenesinde distal simetrik eldiven çorap tarzı hipoestezi, tetraparezi ve hipoaktif derin tendon refleksleri mevcuttu. Hastanın yapılan Elektromiyografisinde akut-subakut sensorimotor polinöropati ile uyumlu bulgular saptandi. Polinöropati etyolojisi açısından yapılan tetkiklerde hipertiroidi saptandı. Tiroid ultrasonografisi otoimmün tiroid patolojisi ile uyumluydu.Tiroid otoantikorları pozitif saptandı.Tiroid patolojisini gösteren bu bulgular dışında bir anormallik saptanmadı. Bunun üzerine hastada otoimmün tirotoksik nöropati düşünülerek hastaya plazmaferez, antitiroid ve kortikosteroid tedavisi verildi, hastanın kliniğinde kısmi düzelme elde edildi ve tedaviye antitiroid tedavi ile devam edildi.

Tirotoksik nöropati, polinöropatinin tedavi edilebilir sebeplerinden biri olması ve laboratuar bulgularıla kolayca saptanabilir olması sebebiyle polinöropati etyolojisinde her zaman akılda tutulmalı ve gerekli tiroid hormonlarının ve tiroid antikorlarının araştııılması unutulmamalıdır.
\end{abstract}

Anahtar Kelimeler: Tiroid, nöropati, otoimmün
ABSTRACT

Thyroid dysfunction can be related to many neurological and psychiatric disorders. Among those, the best known cases are tremor, neuropathies, behavioral disorders, epileptic seizures, headache, encephalopathy, cognitive disorders accompanying to hyperthyroidism and hypothyroidism. A 36 year-old female patient applied to polyclinic with complain of weakness on her hands and difficulty in walking that both had started nearly 1.5 months ago. There was no any related condition in her personal, family and neurological anamnesis. During her neurological examination, while a motor power loss was determined on her each upper and lower proximal and distal extremity and while a distal symmetric hypoesthesia was determined during her sensory examination, on the other hand, aboulia was observed on her deep tendon reflexes for all focal points.Her electromyograhy revealed findings which were coherent with acute-subacute sensorimotor poly-neuropathy. The results of her laboratory tests showed hyperthyroidism. The results of her thyroid ultrasound examination showed the existence of a multi-nodular goiter. Thyroid autoanticors were positive. By taking into account of all those findings, our patients were diagnosed as autoimmune thyrotoxic neuropathy. With this diagnosis, she was applied plasmapheresis, antithyroid agents and corticosteroids. Soon after the end of the treatment, the patient became partially mobilized. Thyroid hormones and thyroid antibodies should be studied further because they are among the remediable causes of polyneuropathy disease and because an early diagnose can prevent neurological and non-recoverably improved cases and also because they can be easily determined via the laboratory tests.

Keywords: Thyroid, neuropthy, autoimmune
KÜ Tıp Fak Derg 2014; 16(2): 37-39

Geliş Tarihi / Received: 10.02 .2014

Kabul Tarihi / Accepted: 27.02.2014
Yazıșma Adresi / Correspondence: Murat ALPUA

Çankırı Devlet Hastanesi, Nöroloji Bölümü, ÇANKIRI

E-posta: dr.muratalpua@yahoo.com 


\section{GíRiş}

Tiroid disfonksiyonu birçok nörolojik ve psikiyatrik hastalıkla ilişkili olabilir(1,2). Bunlar arasında en çok bilinenler hipotiroidide gözlenen kognitif bozukluk ve depresyonla beraber serebrovasküler olay riskinde artıştır(1,2).Bunların dışında hipotiroidi ile birlikte nöbet, ataksi, işitme kaybı ve kraniyal nöropatiler görülebilir. Periferik komplikasyonlar arasında da proksimal miyopati ve karpal tünel sendromu sayllabilir. Yine nadir bir antite olan Hashimoto ensefalopatisi de bilinmektedir.Ayrıca hipertiroidizm; anksiyete, huzursuzluk, irritabilite, emosyonel labilite, konsantrasyon güçlüğü, baş ağrısı ve uykusuzluğa yol açabilir. Hiperrefleksi ve fizyolojik tremorda belirginleşme izlenebilir. Hipertiroidizm kendisi nöbete yol açabileceği gibi epileptik hastalarda nöbeti tetikleyebilir. Tirotoksik kriz halinde ise eşlik eden sistemik bulguların yanı sıra, komaya dek varabilen konfüzyon, ajitasyon görülebilir. Hipertiroidizm ayrıca, bir takım nöromüsküler hastalıklarla da birlikte olabilir. En sık görülen tablo proksimal miyopatidir. Serum CK düzeylerinin genellikle normal olduğu bu vakalarda miyopatinin derecesi tiroid hastalığının ağırlığı ile paralellik göstermeyebilir. Altta yatan tiroid hastalığının tedavisi ile zaaf düzelir. İmmün kökenli iki hastalık olan miyasthenia gravis ve hipertiroidizm birlikte görülebilir. Hipertiroidizm ile birlikte olan diğer bir tablo tirotoksik periyodik paralizidir. Karbonhidrat içeriği yüksek gıda alımını takiben gelişen zaaf atakları potasyum suplementasyonu ile düzelir(1,2). Biz de nadir görülmesi sebebiyle kliniğimizde polinöropati etyolojisi araştırıldı̆̆ı sırada otoimmün tirotoksikoz tespit edilmiş olan ve plazmaferez tedavisine cevabı iyi olan bir olguyu sunduk. .Bu olgu ile tedavi edilebilir polinöropati etyolojisinde otoimmün tiroid hastalığının gözönünde bulundurulması gerekliliğini vurgulamayı amaçladık.

\section{OLGU}

36 yaşında, sağ elini kullanan kadın hasta yaklaşık 1.5 ay önce başlayan ve giderek artan ellerinde kuvvetsizlik ve yürüyememe şikayeti ile polikliniğimize başvurdu.Özgeçmiş, soygeçmiş ve nörolojik anamnezinde bir özellik yoktu.Yapılan fizik muayenesi normal olarak tespit edildi.Nörolojik muayenede; her iki üst ekstremite proksimalinde 4+/5, distalinde $3 / 5$ motor güç mevcut iken, her iki alt ekstremite proksimalinde $4 / 5$, distalinde $1 / 5$ motor güç mevcuttu. Duyu muayenesinde distal simetrik hipoestezi varken, derin tendon refleksleri yaygın olaral elde edilemedi. Ekstremite distallerinde belirgin atrofi izlendi.

Yapılan laboratuar incelemelerinde serbest T3: 4.02 (2.5-3.9 pg/ml), serbestT4: $1.11 \quad(0.61-1.2 \mathrm{ng} / \mathrm{ml})$, TSH:0.05 (0.34-4.25), antitiroid peroksidaz: 1087 (<9IU/ml), antitiroglobulin: 7.6 (<4IU/ml), TSH reseptör antikoru: $13.6(<1.5 \mathrm{IU} / \mathrm{l})$ idi. Yapılan tiroid USG'de multi nodüler guatr tespit edildi. Yapılan tiroid sintigrafisi de diffüz hiperplazik tiroid bezi ile uyumluydu. EMG'de ağır derecede, akut-subakut sensorimotor polinöropati ile uyumlu bulgular izlendi. Olgumuzda tüm bu bulgularla, nadir görülen bir klinik antite olan otoimmün tirotoksik nöropati düşünüldü ve hastaya 5 seans plazmaferez uygulandı. Plazmerez seanslarının tamamlanmasından kısa süre sonra hasta kısmen mobilize hale geldi ve sonrasinda antiroid tedavi ile birlikte prednizolon tedavisi başlanarak taburcu edildi.

\section{TARTIŞMA}

Tirotoksikoz diğer hiçbir sistemik tutulum göstermeden birçok nörolojik sendromla prezente olabilir $(1,2)$. Bunlar arasında myopati, periyodik paralizi,oftalmopleji ve myastenia gravis sayllabilir $(1,2)$. Bizim olgumuzda da sistemik herhangi bir semptom olmadan nörolojik tablo kliniğge hakimdi. 
Olgumuzda, klinik öykü ve yapılan nörolojik muayene sonrasında öncelikli olarak polinöropati düşünüldü. Bunun üzerine yapılan EMG incelemesinde ön tanımızı destekler şekilde akut-subakut sensorimotor nöropati ile uyumlu bulgular saptandı. Polinöropati etyolojisine yönelik olarak yapılan rutin hemogram ve biyokimyasal testlerde sistemik hastalık düşündüren bir patoloji saptanmad. Vitamin B12 ve folik asit düzeylerinin normal olması bu vitaminlerin eksikliğine bağlı görülen polinöropati tanısından uzaklaştırdı. Ülkemizde brusella enfeksiyonu endemik olarak bulunduğundan ve polinöropati etyolojisinde de yer aldığından dolayı $(3,4)$ hastamız bruselloz açısından araştırıldı ve kan ve beyin omurilik sıvısı (BOS) brusella antikor titreleri negatif saptandı. Dolayısıyla brusellaya bağlı polinöropati tanısından uzaklaşıldı. Ayrica hepatit, HIV, borrelia serolojisi de negatifti. Hastanın soygeçmişinde herhangi bir özellik olmaması bizi herediter nöropatilerden uzaklaştırdı. Öyküsünde herhangi bir toksik madde maruziyeti belirtilmedi. Diğer polinöropati nedenlerinden olan diyabetes mellitus, üremi ile giden böbrek hastalığı ve alkol kullanım öyküsü mevcut değildi. Hastanın vaskülitik etyoloji açısından yapılan vaskülit tetkikleri içinde sadece antinükleer antikor pozitifliği tespit edildi. ANA poziftiliği nedeni ile hasta Romatoloji kliniği ile konsülte edildi ve mevcut pozitifliğin sistemik bir vaskülit lehine değerlendirilemeyeceği belirtildi. Ancak pozitif olması, ANA pozitifliğinin eşlik edebildiği, altta yatan başka otoimmün bir etyoloji olabileceğini akla getirdi. Hastanın bakılan tiroid fonkisyon testlerinde tirotoksikoz saptanması ve tiroid otoantikorlarının pozitif gelmesi üzerine hastada otoimmün tirotoksik polinöropati düşünüldü. Hastanın tedavisi düzenlendi ve immunoterapiden hasta anlamlı şekilde fayda gördü.

Otoimmun tiroid hastalığının teşhisinde kullanılan testler tiroid fonksiyon testleri, tiroid otoantikorları, tiroid ultrasonografisi, sintigrafisi ve radyo-aktif iyot uptake testidir. Bizim hastamızda da serbest T3 düzeyi yüksek, serbest T4 düzeyi normal, TSH baskılı ve tiroid otoantikorları anlamlı şekilde pozitifti ve polinöropati tespit edilen olgumuzda polinöropatiye sebep olabilecek başka bir etyoloji bulunmadı.Bu sebeple nadir bir klinik antite olan otoimmün tirotoksik nöropati düşünüldü.

Tirotoksik nöropati antitiroid tedavi ile birlikte düzelir (5).Olgumuzda yapılan plazmaferez seansları sonrası ve bu seanslar sonrası başlanan antiroid tedavi ile birlikte immünsupresif tedavi sonrasında hastanın kliniğinde anlamlı derecede düzelme olması bu olgudaki tanımızı destekledi.

Polinöropatinin tedavi edilebilir sebeplerinden olması ve erken tanının, ortaya çıkabilecek ve geri dönüşümsüz nörolojik tabloların önlenmesinde önemi olduğundan, laboratuar olarak tanınması oldukça kolay olmasından dolayı tiroid hormonlarının ve tiroid antikorlarının araştırılması gereklidir (6). $\mathrm{Bu}$ olguyu sunmamızdaki temel amaç sebebi ortaya çıkarılamamış nörolojik semptomlu olgularda tedavi edilebilir tiroid hastalığının araştırılmasının önemini vurgulamaktır (6).

\section{KAYNAKLAR}

1. Burness CE,Shaw PJ .Thyroid Disease and Nervous System. Aminoff MJ. Neurology and General Medicine. 4th edition. Churchill Livingstone. Elsevier. p.357-375

2. Roberts AH. Br Med J. Neurological complications of systemic diseases. II. 1970; 1(5688): 95-7.

3. Bilen S, Güneş HN, Saka M, Ak F.-Four different clinical manifestations of neurobrucellosis (case reports). Eur J Intern Med. 2008; 19(8): e75-7.

4. Kutlu G, Ertem GT, Coşkun O, Ergun U, Gomceli YB, Tulek N, Inan LE Brucella: A cause of peripheral neuropathy. Eur Neurol. 2009; 61(1): 338.

5. Pandit L, Shankar SK, Gayathri N, Pandit A.Acute thyrotoxic neuropathy-Basedow's paraplegia revisited. J Neurol Sci. 1998; 155(2): 211-4.

6. 6-Sahni V, Gupta N, Anuradha S, Tatke M, Kar P.Med J Malaysia.Thyrotoxic neuropathy- an under diagnosed condition.2007;62(1):76-7. 